\title{
E-Waste and the Sustainable Organisation: Griffith University's Approach to E-Waste
}

\author{
*Georgina Davis, Malcolm Wolski \\ Griffith University, Australia
}

* Corresponding Author:

Dr Georgina Davis

Centre for Environmental Systems Research

Griffith University

Nathan Campus

170 Kessels Road

Nathan

Brisbane

QLD 4111

AUSTRALIA

Telephone: 0061737112496

Fax: 0061737357404

E-Mail: g.davis@griffith.edu.au

\section{Bionote}

Dr. Georgina Davis is a Research Fellow within the Centre for Environmental Systems Research at Griffith University. She obtained her Doctorate of Engineering in Environmental Technologies from Brunel University, London, and was previously employed within the Engineering Management Group at Bristol University, UK, before emigrating to Australia in 2006.

Mr Malcolm Wolski is the Associate Director for Information and Communication Technology Services at Griffith University. 


\section{Structured Abstract: Case Study Paper}

\section{Purpose}

This paper provides details of Griffith University's (GU) approach for sustainably dealing with electronic waste (e-waste) and the benefits of using the e-waste programme as a valuable educational case study for ESD.

\section{Design/methodology/approach}

The e-waste programme is explained with reference to key resources and literature, so as to provide a practical approach for any organisation looking to sustainably manage its e-waste stream. The rationale and structure for the e-waste educational case study is also presented so that other academics may use it as a template or study aid within their own teaching.

\section{Findings}

The paper provides references to web resources and GU internal resources so that readers can access valuable information, and to show how those resources can be applied to their own organisation. The paper also identifies and discusses the factors, which may hinder the implementation of a sustainable e-waste programme.

\section{Research limitations/implications}

The paper has been written to be as succinct and as accessible to readers as possible and, as such, has not presented each of the aspects of the sustainable e-waste programme in depth. This information, for those requiring more detail, is accessible through the resources presented.

\section{Practical implications}

A useful source on how e-wastes can be sustainably managed by Universities and presentation of a modelled approach.

\section{Originality/value}

This paper highlights an individual response to an increasingly complex and potentially polluting and unsustainable waste stream. It aims to provide a practical institution-wide approach for dealing with e-wastes; and in particular, seeks to raise the awareness of the issues associated with e-waste to those institutions who may not be aware. 


\begin{abstract}
The term e-waste refers to any item of discarded electronic equipment, regardless of value or condition (operational or non-operational). This paper describes the approach taken at Griffith University, Queensland, for the management of their e-wastes as part of a 'sustainable campus' regime. The Griffith approach includes the formulation of an e-waste policy, which sought to address the key factors including definitions, legal requirements, data and software security, protection of the environment, and social responsibility. The policy was supported by an accompanying report entitled 'Processing and Treatment of Electronic Waste Generated from Computers within Griffith University'.

The report identified institutional regimes which may impede optimal resource recovery and discussed the adequacy of current organisational data relating to electronic equipment. Ten recommendations were formulated to identify how resource efficiencies could be optimised to positively progress economic, environmental and social standards. These recommendations include the identification of stakeholders (internal and external), opportunities for collaboration, green purchasing guidelines and new suitable recording and auditing regimes which included the formulation of key performance indicators to monitor progress. The recommendations from that report have been presented within this paper as an aid to other organisations wishing to review their own practices.

The e-waste initiative at Griffith also formed an e-waste case study, which has both been an effective teaching tool for promoting best practice and acting as a practical case study for students.
\end{abstract}

Keywords: e-waste; sustainability, sustainable campuses, sustainability helix. 


\section{Introduction}

To date, there have been many variations on the definition of sustainable development which has led for a call for a universal definition prior to the development of any institutional or educational programme. Understandably, this variation is due to the complexity of the issues, the dynamic environment, various personal view points and personal interpretation.

One of the most popular definitions is that contained within 'Our Common Future' (World Commission on Environment and Development, 1987) "Humanity has the ability to make development sustainable - to ensure that it meets the needs of the present without compromising the ability of future generations to meet their own needs".

Sustainable development is the most significant challenge to universities at present (van Weenan, 2001). Several universities around the world have made commitments to promote strategies for creating more sustainable universities, through their teaching, their campuses and their management. This has been accompanied by a series of international declarations such as the Thessaloniki Declaration (1997), which stated "all subject disciplines must address issues related to the environment and sustainable development and that university curriculum must be reoriented towards a holistic approach to education”.

Globally, universities are dealing with the challenges of sustainable development in diverse ways and at many different levels. The areas of inclusion for sustainable development range from teaching and research, to the core management and marketing of an institution. Van Weenen (2001), proposed a model for a sustainable university, which included four levels of university engagement. At level 1 it is essential to consider the operations of the university, such as energy and facilities; Level 2 covers inclusion of sustainability in research and education; Level 3 involves the engagement of university management in formulating new policy and collaboration with external organisations; and finally, Level 4 involves the formulation of a mission statement reflecting the core values which would act as a motivator and support mechanism, highly visible to both internal and external stakeholders.

This paper describes the approach taken by Griffith University in order to sustainably manage its electronic waste (e-waste) and how this approach was effectively used as an educational case study to undergraduate and postgraduate environmental engineering students undertaking modules in solid waste management, solid waste engineering and hazardous waste management.

\section{E-Waste: The Underlying Principles}

E-waste is defined as "all obsolete or outdated computers, televisions, cell phones, printers, PDAs, and thousands of other devices commonly used in offices, homes and by people on the go" (Electronic Recyclers of America, 2006). Electronic items (such as computers and peripherals and visual display equipment) are essential for a university to function and realise its research and education aims. 
It is accepted that no single option will effectively or efficiently deal with the electronic waste being generated within an organisation. There are also ongoing issues surrounding the timely disposal of equipment, which may be held in storage for several months before 'disposal' (sale or scrap) after being written-off. This period of storage can effectively diminish the auction/resale value of equipment sent for sale and can pose both storage and health and safety issues.

The increase in consumption of smaller electronic items, such as PDA's and mobile phones, coupled with lowering purchase costs of new electronic equipment, is resulting in an increase in "consumerables" and a decrease in "assets" across some organisation. Thus the monitoring of an increasing amount of electronic equipment is becoming harder for many organisations.

Currently, there is no specific computer waste legislation being considered within Australia and any national strategy would, most likely, be voluntary. Without strict regulation or mandatory legislation, there is little incentive for manufacturers and suppliers of electronic equipment to implement costly recycling or take-back schemes, and without the take-back schemes there is even less motivation to implement greendesign principles or active design for disassembly (Davis, 2007).

It is commonly acknowledged that current costs associated with the purchase of electronic equipment do not embrace these principles, as all costs associated with the use of a resource are not included in the price of goods and services developed from that resource. Additionally, the cost of disposal across Australia does not accurately cover all externalities such as environmental and social impacts. Also the producers or importers of the electronic goods purchased by commercial organisations do not take all reasonable steps to minimise environmental harm from the production, use and disposal of the product as they could in line with the "product-stewardship principle".

An organisation needs to accept the 'polluter-pays' and 'user pays' principles, which are key to achieving good waste management practice and long-term protection of the environment. Certainly IT departments now need to view themselves as waste producers.

The Council of Australian University Directors of Information Technology (CAUDIT), commissioned a report in 2005 to determine the scope and issues regarding e-wastes within universities. The report included the results of a questionnaire sent to representatives in ten universities (including Griffith) to determine actions on purchasing, end-of-life, and policy issues concerning waste electronic equipment.

The survey concluded several key points including (CAUDIT, 2005):

- Purchasing:

o Purchasing was usually undertaken by Finance Departments with little input from IT departments, and price appears to be the main consideration;

0 The average turnover for units was 3-4 years, and the average quantity purchased was 5,000; 
o The only environmental consideration in the tender process was energy consumption.

- End-of-Life:

o End-of-life responsibility ceased when the equipment left the campus;

o All leased machines were assumed to be resold or recycled;

0 There was no awareness of the percentage of equipment being sent to landfill or overseas.

- Policy:

o There were no e-waste policies or individual environmental or social policies relating to e-waste;

o There was a lack of awareness of individual responsibility for e-wastes.

\section{Griffith University's Role in Sustainability and E-Waste}

Griffith University, Queensland, has five campuses (Nathan, Mount Gravatt, Gold Coast, Logan and South Bank). Across these campuses there are over 8,000 computers and associated peripherals, in addition to other electronic equipment. These computers are typically replaced at a rate of around 2,000 per annum (2,400 in 2005), thus computers are a significant component of the electronic waste stream across the campuses.

To date, the end-of-service units are disposed of to three main routes (Figure 1):-

1. Sale by public auction through an approved auction house. This is the preferred option for operational equipment (670 in 2005);

2. A small amount of working computers distributed through the existing 'Student Equity Scheme' operated by Student Services (70 in 2005);

3. If the equipment is non-operational, it is given free-of-charge to a local scrap metal recycler (330 in 2005).

Some equipment is also written-off due to theft, cannibalisation of components, and insurance claims. Originally, any residual computer components were frequently discarded in with general waste. To date, the rate of acquisition has been exceeding the rate of disposal (i.e. the fleet is both growing and aging). 


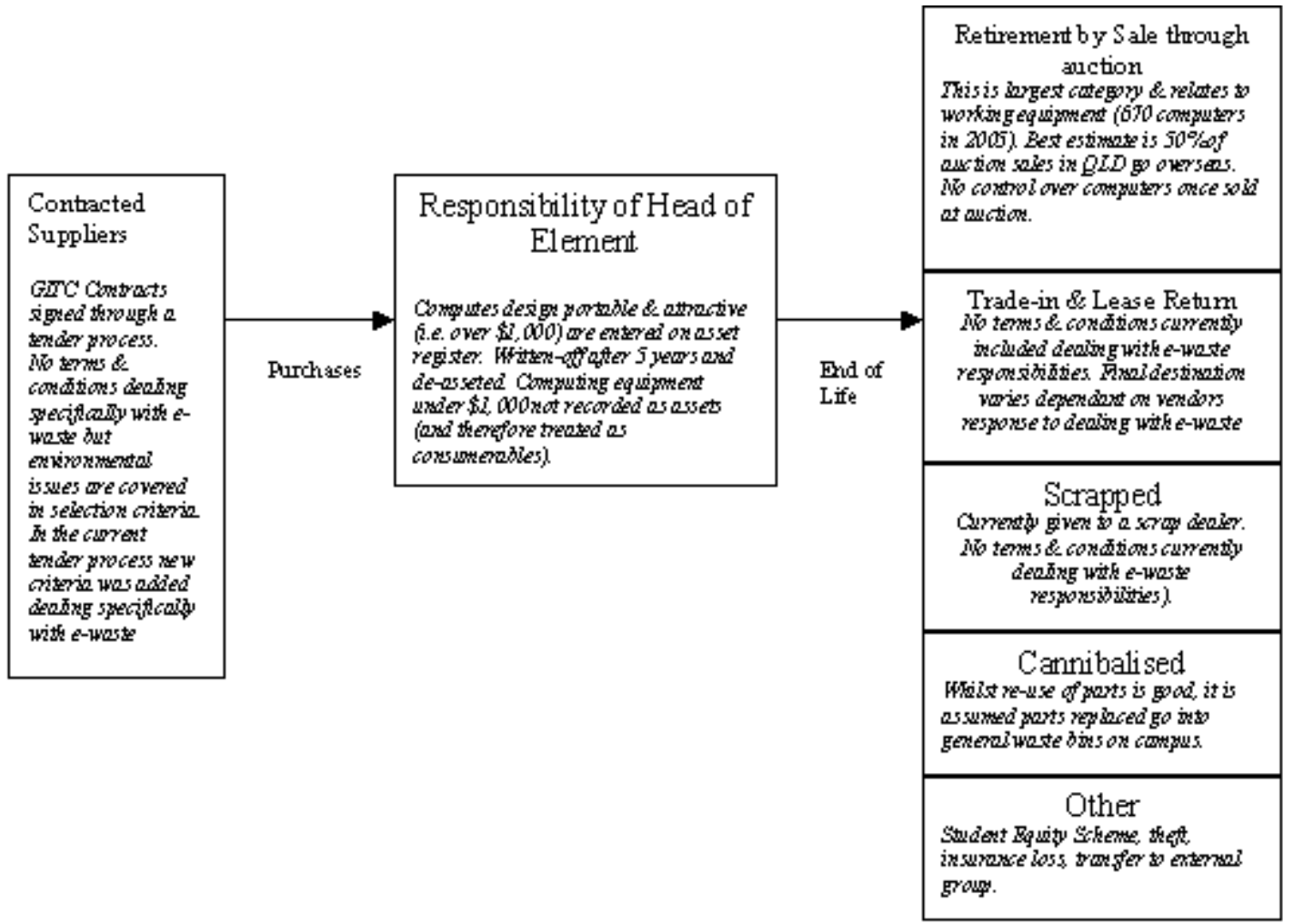

Figure 1: Typical Computers E-Waste Flow on Campus

During 2005, Griffith retired over 1,100 electronic items that were registered as assets, comprising of computers, laptops, printers and other peripherals. Of these, 670 items were 'retired by sale' and 328 items were scrapped (with zero value). Although auction sale prices vary considerably, the current median price is around AU\$40 a unit, and decreasing annually.

There are three main reasons for pursuing alternative solutions for dealing with disposal of computers. Firstly, Griffith University is currently 'greening' its campuses in an effort to achieve greater sustainability and has an increasing realisation of its social and environmental responsibilities associated with sustainability principles. While Griffith's computer fleet may be reasonably stable, numerous other electronic items are being purchased, such as mobile phones, DVD's, digital camera's and PDA's. There is also a trend to replace more desktop PCs with laptops. None of the previously mentioned disposal routes for waste computer equipment allow Griffith any influence or involvement in determining if the final route (treatment through to disposal) complies with their own objectives and aspirations, and therefore may not be moving towards closing the materials loop, which is necessary for sustainability.

Secondly, overseas countries have already introduced legislation restricting disposal of electronic waste. E-waste is on the agendas of the Australian Federal government, Queensland government and local authorities. By dealing with the issue now, Griffith will be in position to respond to any future legislation and regulations. Finally, there is an opportunity for Griffith to demonstrate leadership within the community in responding to the environmental issue. 
In order to be sustainable, Griffith University must reduce its environmental impact via more efficient use of resources, whilst ensuring that all stakeholders are not negatively impacted and continue to benefit from their association with the University.

Griffith has been involved in a number of activities to establish its credentials in relation to addressing e-waste. These include:

- Organisation of the first public collection day in Queensland for 'old' computers in May 2006 which was held in partnership with DELL Computing Australia.

- Web presence www.griffith.edu.au/e-waste where current e-news and results from ongoing research are posted.

- Incorporated e-waste in the Sustainable Living Challenge a 'Natural Edge Initiative' (http://www.naturaledgeproject.net/) with funding obtained from Hewlett-Packard.

- Held an e-waste workshop in Brisbane for a variety of industry, government, and university stakeholders.

- Presented at a number of conferences on the subject and issues of e-waste, including research results.

- A project commissioned by the Gold Coast City addressing their e-waste problems

- Undertook a project on behalf of the Australian and New Zealand Universities' Directors of Information Technology, to provide an assessment of the e-waste issue and make recommendations on how to address the problem.

- Conducted a series of lunch time seminars for both Griffith and Queensland University of Technology (QUT) staff.

- Information Services working with the Eco Centre and the Faculty of Environmental Sciences have partnered with Dell Computers Australia, HewlettPackard P/L and Ricoh in finding solutions for e-waste.

- Undertook Australia's first Local Council e-waste survey which sought to identify the current level of understanding and action on e-wastes, and to identify the key barriers experienced by Councils regarding the collection and treatment of ewastes.

- The surveying of Local Councils across Australia to determine the actual barriers and opportunities for e-wastes across the states. This work has been disseminated through trade press and peer-review journal papers.

- The identification of key stakeholders and industry networking.

- Professor David Thiel, from Griffith School of Engineering has developed the patented e-waste technology known as Circuits in Plastic.

\section{E-Waste and the Sustainable Organisation}

Resolving the e-waste issue within any establishment (private or public) should be seen in the context of achieving the goal of becoming a sustainable organisation. The Sustainability Helix framework (Hargroves and Smith, 2005) is a useful process to follow to move forward in addressing e-waste, and provides a non-linear, matrix style approach that can be implemented from day one (Figure 2). 


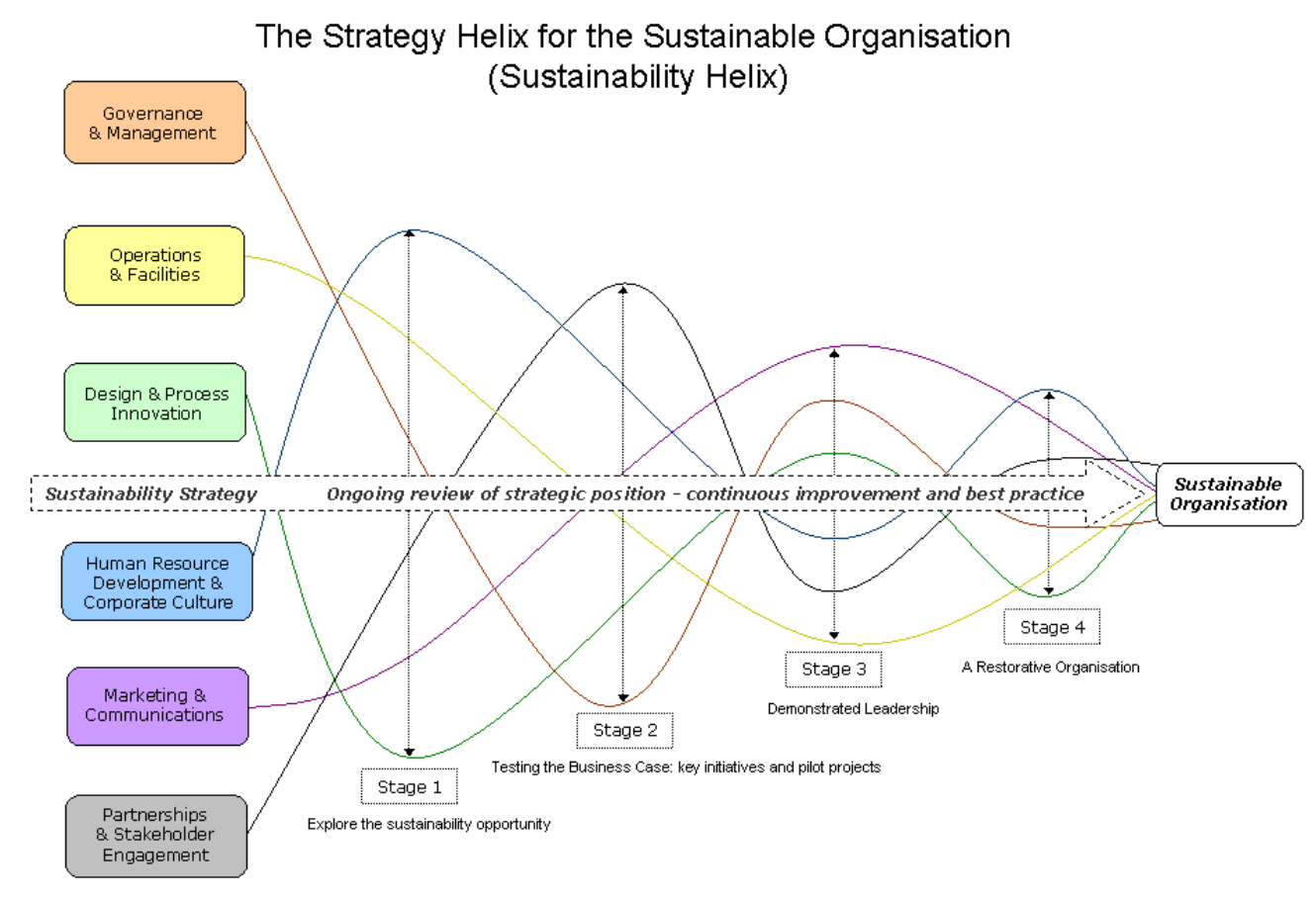

Copyright 2005 The Natural Edge Project, Natural Capitalism Inc and Sustainable Business Practices

Figure 2: The Sustainability Helix (Hargroves and Smith, 2005).

In order to assist Griffith with the implementation of sustainability for e-waste, a checklist was initially devised to identify the issues associated with e-waste management. The document posed a series of comprehensive questions, which addressed a range of issues using the headings within the sustainability helix framework. This document can be viewed at Griffith's E-Waste web-page (www.griffith.edu.au) as guidance for other organisations wishing to address their ewaste stream.

The following considerations were noted and developed within Griffith for dealing with e-wastes (Davis and Wolski, 2007). To develop a comprehensive response to deal with e-waste, upper management support is necessary and the adoption of a formal e-waste policy would introduce guidelines for the social and environmentally responsible management of used and waste electronic equipment from all premises. A policy should indicate top-down support and assign responsibilities for the management of e-wastes. The aims of the policy should reflect the organisation's requirements and reflect their commitment for sustainability. The Griffith approach includes the formulation of an e-waste policy, which sought to address the key factors including; definitions, legal requirements (including guidelines for the disposal of assets and consumerables), data and software security, protection of the environment, and social responsibility. The policy was supported by an accompanying report entitled 'Processing and Treatment of Electronic Waste Generated from Computers within Griffith University' which set the scene for e-waste management within Australia and globally. The report also identified institutional regimes, which may impede optimal resource recovery and discussed the adequacy of current organisational data relating to electronic equipment. 
The leasing of electronic equipment, although helping to 'close the loop' for an organistion, may find that the the leasing company still disposes of the equipment at its end-of-lease period in a manner which is not in line with the principles of sustainability, nor those of the company's social or environmental aspirations and core values.

To ensure electronic waste is dealt with in an appropriate manner, sale of operational electronic equipment to external agencies (e.g. refurbishers, recyclers, auction houses and brokers) the following contract specifications are recommended as a minimum (Davis and Wolski, 2007):

- The company will assume all title upon equipment collection releasing the organisation from any future environmental liability.

- All computer hard drives are securely stored and then erased or rendered inoperable, protecting the organisation from software pirating and release of sensitive data.

- All traces of ownership by the organisation will be removed, including the removal ID's, asset tags and any engravings that may identify the equipment's original owner.

- All equipment is pulled apart and/or directly segregated into the appropriate recycling categories before forwarding to the various reprocessors.

- Where possible, selected and assessed re-useable computer components and equipment will be made available to the second hand market for re-use. Again with regard to the previous points.

- A detailed report providing details of the services performed and resource flows (by weight) should be requested and supplied punctually on a regular basis.

It is also worth enquiring with the leasing company if any opportunity for charitable or community donation exists.

In order to address sustainability issues for tenders for the supply of computers, additional criteria should be requested from potential suppliers to detail how they address environmental standard IEEE 1680 in relation to (IEEE, 2006):
- $\quad$ Toxics Reduction;
- $\quad$ Material Selection;
- $\quad$ Design for End of Life;
- $\quad$ Life-cycle extension;
- $\quad$ Energy Conservation.

Interested suppliers should be able to respond to this question by providing details of compliance of their products and services using the criteria in the Electronic Product Environmental Assessment Tool (EPEAT) sections 4.1 through to 4.5, available at http://www.epeat.net/Criteria.aspx

However, given that all electronic items add to the e-waste stream, a more holistic approach is required. Green procurement guidelines require the formulation and adoption of purchasing policies which specify criteria for all new electronic equipment, not just computers. Initially, these criteria can be set around improving 
the end-of-life management of products, with inclusion of take-back programs requiring reuse and recycling of materials, and even minimum standards for upgrading machines.

An approach for 'preferred' suppliers may also be chosen, for example, those accredited to the Blue Angel or other labelling scheme (information can be viewed on www.griffith.edu.au/blogs/sustainability). The introduction of new policy measures, coupled with the revision of existing procurement strategies, must ensure that an organisation can meet sustainability criteria for environmentally responsible purchasing (ERPP). It is also possible to align current practice to the National Voluntary Tools for Environmental Purchasing, which include the Environmental Purchasing Checklists for 'Personal Computers and Monitors' and 'Office Equipment Consumerables’ (www.deh.gov.au/settlements/government/purchasing/index.html).

Under tender conditions for all electronic equipment, an organisation could specify conditions to include:-

- The labelling of components for recycling;

- Energy usage during in-service life-time (as in IEEE 1680);

- The life expectancy of equipment;

- Take-back of products for recycling or appropriate disposal.

This would represent a significant move in incorporating environmental considerations in purchasing decisions.

Performance Indictors (PI's) are often used in contracts between two parties (typically an organisation and its contractor) in order to determine whether contractual goals and obligations are being met. Some organisations, such as Local Governments, use PI's to monitor performance over time or to 'bench-mark' their performance against other similar organisations (Davis and Wolski, 2007).

Any PI set needs to be meaningful and requires clear methodologies relating to data collection and processing to ensure the process is transparent and repeatable for all stakeholders. Finally, they have to be realistic in terms of data acquisition and the resources required to both monitor and report them. PI's could include:

- Electronic waste generation (units per month, per year);

- Waste Disposal Index (no. of electronic units 'written-off'/net additions to stock);

- No. of units sent for disposal and recycling;

- Total net cost of selected option.

The average computer user in an organisation may be unaware of the scope of the problem of disposal of waste electronic and computer equipment in relation to financial and regulatory guidelines, and issues relating to data protection. Whilst some users may be aware of their individual difficulty in locating an appropriate recycling or disposal pathway for their end-of-life electronic equipment, they may not be fully aware of the nature of hazardous materials used in computer manufacture and the requirement for special disposal, particularly if classified as hazardous waste. 
How to address the e-waste issue needs to be integrated into staff development activities to ensure that it becomes a part of the culture in the organisation. Suggested avenues include:

- Incorporation of sustainability (including e-waste) into staff induction and development activities.

- Dissemination of information through posters, leaflets, intranet.

- Developing a Course (short course \&/or for credit) for Senior Staff for Developing the Sustainable Organisation.

- Address e-waste in any office/building management operations.

After investigation, ten recommendations identified within the report "Processing and Treatment of Electronic Wastes Generated from Computers within Griffith University”, are currently being considered by Griffith management:

1. Griffith adopts an e-waste Policy.

2. Investigation of formal policies \&/or strategies relating to the management of solid wastes/resources generated across its campuses specifically addressing electronic waste.

3. The University issue a Request for Information on a solution to dispose of old computers and components, specifying criteria to ensure electronic waste is dealt with in appropriate manner. The student equity scheme should be included as an optional service at tender.

4. Investigation and costs options for separate collection and disposal of electronic waste on all campuses.

5. That the University align their current practice to the National Voluntary Tools for Environmental Purchasing, which includes the Environmental Purchasing Checklists for 'Personal Computers and Monitors' and 'Office Equipment Consumerables'.

6. Develop and implement performance indicators to measure compliance and progress against targets.

7. Staff development and education programs to address sustainability and ewaste issues within the organisation.

8. Further develop the existing Green Office program to address the e-waste issue.

9. Establish a Sustainable Organization Program Board within Griffith using ewaste as the initial activity to develop the sustainable organisation culture and bring about change. Market and promote progress in the larger community.

10. Investigate the potential of establishing Sustainable Organisation Industry Partners as a means to engage with industry, and market the partnerships for mutual benefit using e-waste as a starting point.

Signficant progress against many of these recommendations has been made to date, including the development of an e-waste policy; delivery of a series of staff development lunch-time seminars to both Griffith and neighbouring university staff; revised tender specifications for computer suppliers; development and reporting against performance indicators and synergies to green office programmes.

\section{E-Waste: An Educational Case Study}

The use of 'localised' case studies can provide students with good resource material. For example, linking the course to the University’s own Environmental Management 
System (EMS) or management of e-wastes, not only demonstrates the University's commitment to sustainability but also provides current data within a practical industry led model (Davis, 2006).

Other studies have also highlighted the importance of case studies in the education of sustainable development, although not all have used the terminology 'case-study', rather identifying good education for sustainable development (ESD) practice through the "dissemination of creative and imaginative projects" (Blewitt, 2001); or drawing on existing internal research on sustainable development and disseminating the key findings through the academic courses (Fenner et al., 2005).

Such a philosophy has already been adopted by some universities. One such university is Bradford, UK, (DEFRA, 2006) who is currently creating a sustainable campus at its city centre site. The 'Ecoversity' project will transform the campus environment, whilst also aiding community engagement, supporting business generation and educating students, staff and the community about sustainability. The University's aim is to deliver a student experience incorporating learning and participation in sustainability, through 'engaging students and propagating the skills and knowledge needed in the pursuit of sustainable development'. Demonstration areas will include space for teaching and conducting research, in addition to showcasing environmental technologies.

Although case studies are a useful teaching tool for the understanding of sustainable development, it is essential that any case studies include how the subject can be integrated into teaching practice. Also some case studies are timely and their subject matter will become out of date or superseded by a superior example, and therefore require regular review and revision to remain current and to furnish students with the latest knowledge. However, it is acknowledged that this process is resource consuming, as is the initial development of any case study. The resource requirement, in particular that of time, is one of the prominent barriers to the adoption of more 'sustainable development' case studies within the curriculum (Davis, 2006).

The e-waste educational case study at Griffith University was written to follow a standardised format already utilised by the Engineering Subject Centre, UK (EngSC). The EngSC (2005), commissioned a series of 'briefing papers in education for sustainable development'. Each EngSC case study can be disseminated as a teaching resource in its own right, or as a briefing paper that introduces the individual topic to the academic; through its comprehensive bibliography/references listing. The academic can then develop that material to their chosen level. Together, the papers form a collated series of case studies on topics in sustainable development, to facilitate the introduction of sustainability issues into the curriculum by academics with a responsibility for education for sustainable development (ESD).

The e-waste case study has several mandatory fields that are essential for the understanding and delivery of the topic, including an 'adoption section' which notes how it was taught by the author, the implementation of the topic (actual/predicted), accompanied with real-life examples to illustrate and inform the reader of its adoption into teaching. This approach provides other tutors with the flexibility to adopt the 'off-the-peg' e-waste resource which best fit their teaching strategies and learning outcomes and require no additional or only limited additional resources to customise. 


\section{Conclusion}

The increase in consumption of smaller electronic items, such as PDA's and mobile phones, coupled with lowering purchase costs of new electronic equipment, is resulting in an increase in "consumerables" and a decrease in "assets" across many Universities. Consumerables, under many guidelines are categorized differently from assets and are not recorded within asset management systems and, as such, the monitoring of an increasing amount of electronic equipment is becoming harder, as its disposal is becoming easier, given the reduction in size and cost of such equipment.

The process to achieve 'sustainable campuses' is viewed by Griffith to be dynamic, requiring the continuous design and implementation of policy and strategy with full collaboration and the assignment of responsibilities throughout departments.

The formation and dissemination of an e-waste policy and its accompanying report successfully increased awareness at a variety of levels of electronic wastes (e-waste) throughout the university, including the current and future issues associated with their sustainable management. By taking a staged approach to the issues associated with the sustainable management of e-wastes, Griffith has been able to ensure a logical and timely progression towards the ten recommendations noted in its report ensuring management support and university-wide understanding of the issues. It is hoped that the approach used by Griffith may be applicable to other institutions wishing to effectively and sustainably manage their e-waste stream.

By raising the profile and awareness of the e-waste stream across all Australian universities, it will be possible to disseminate best practice and also to form collaborative partnerships to better manage this waste stream. For example, despite the large number of computers purchased by individual universities, undoubtedly a collaborative purchasing approach which uses standardised sustainability criteria for tenders across all universities would have greater influence. It would also allow the tertiary education sector to lead in the sustainable management of e-wastes, acting as a model to other organisations.

With regard to e-waste and education, sustainable development is truly an interdisciplinary subject, requiring a minimum of educational awareness in the social, environmental and economic disciplines and the ability to develop holistic thinking approaches within and between the disciplines. Although these skills exist within universities as a whole, they may not yet be developed within a single department or faculty (Davis, 2006). E-Waste however, is generated across all university departments and, as such, requires joint action regardless of discipline or department.

In order to achieve education for sustainable development, it is necessary to give individuals/students more than simply the knowledge and skills for recognising sustainable development, but also the capacity to develop sustainable development practices in their 'own world'. By introducing a case study, students can actively engage in, and witness change within the institutional learning-place. An e-waste case study is therefore tangible to students and other internal stakeholders, clearly demonstrating an institutions commitment to sustainable development. 


\section{References}

Blewitt, J. (2001). Good Practice in Sustainable Development Education: Evaluation Report and Good Practice Guide. Learning and Skills Council, UK.

CAUDIT. (2005). Electronic Waste Report. Griffith University on behalf of the Council of Australian University Directors for Information Technology. May 2005. http://www.caudit.edu.au/index.php/search/

Davis, G., Herat, S. (2007). Managing E-Waste at Local Government Level in Australia: Opportunities and Barriers. $22^{\text {nd }}$ International Conference on Solid Waste Technology and Management, Philadelphia, US. $18^{\text {th }}-21^{\text {st }}$ March 2007.

Davis, G. U. (2006). The Use of Case Studies for Integrating Sustainable Development into the Education of Engineers. World Transactions on Engineering and Technology Education. UNESCO International Centre for Engineering Education (UICEE). Vol.5 No.1, 159-163.

Davis, G., Wolski, M. (2007). Towards Sustainable Management of Electronic Wastes: Policy Development and Implementation - A Case Study from the Tertiary Education Sector. Paper and Poster. $22^{\text {nd }}$ International Conference on Solid Waste Technology and Management, Philadelphia, US. $18^{\text {th }}-21^{\text {st }}$ March 2007.

Department for Environment, Food and Rural Affairs (DEFRA). (2006). First Steps Towards Campus Sustainability. Energy, Resource, Environment and Sustainable Management. (Jan/Feb 2006).

Electronic Recyclers of America. (2006). The History of E-Waste: E-Waste Defined. http://www.electronicrecyclers.com/historyofewaste.aspx

Engineering Subject Centre, UK. (2005). Briefing Papers in Education for Sustainable Development: Energy and Energy Systems Edition. www.engsc.edu.au.

Fenner, R., Ainger, C.M., Cruickshank, H.J, Guthrie, P. (2005). Embedding Sustainable Development at Cambridge University Engineering Department. International Journal of Sustainability in Higher Education. Vol 6, No.3, 229-241.

Hargraves, K., Smith, M. (2005). The Natural Advantage of Nations. The Natural Edge Project. Earthscan.

IEEE (2006). Institution of Electrical and Electronic Engineering (now IEEEE). IEEE standard 1680. http://standards.ieee.org/.

Thessaloniki Declaration. http://www.unesco.org/education/esd/english/international/thesdecl.html. Retrieved $10^{\text {th }}$ July 2007.

Van Weenen, H. (2000). Towards a vision of a sustainable university. International Journal of Sustainability in Higher Education. Vol. 1 No.1, 20-34.

World Commission on Environment and Development. (1987). Our Common Future. Oxford University Press, Oxford. 